\title{
Study on impact of silver nanoparticles synthesized using aqueous extract of Ganoderma applanatum on thyroid and lipid parameters of albino rat
}

\author{
Sukumar Dandapat, Rohit Srivastava \& Manoranjan Prasad Sinha \\ Department of Zoology, Ranchi University, Ranchi-834008, Jharkhand, India.
}

Correspondence
S. Dandapat
E-mail: dr.sukumar2018@gmail.com
Received: 6 November 2020
Accepted: 21 April 2021
Published on-line: 9 November 2021

Published on-line: 9 November 2021

\section{Resumen}

Estudio del impacto de las nanopartículas de plata sintetizadas con extracto acuoso de Ganoderma applanatum sobre los parámetros tiroideos y lipídicos de la rata albina

Se estudió el impacto de SNP cargadas con extracto de Ganoderma applanatum sobre el perfil tiroideo y lipídico de rata. Las SNP (diámetro medio $58,77 \mathrm{~nm}$; potencial zeta - 3,8) $\mathrm{mV}$ se analizaron mediante DLS. La microespectroscopía de infrarrojo con transformada de Fourier proporcionó un pico de transmisión amplio y elevado a $3248,12 \mathrm{~cm}^{-1}$, que indica la carga bioquímica del extracto de G. applanatum en la superficie de los SNP. No se observó mortalidad ni cambios de comportamiento en la prueba de toxicidad aguda. El grupo-1 recibió $1 \mathrm{~mL}$ de agua destilada, el grupo-2 y el grupo-3 recibieron $200 \mathrm{mg} \mathrm{kg}^{-1}$ y $400 \mathrm{mg} \mathrm{kg}^{-1}$ de nanopartículas respectivamente. Una dosis de $400 \mathrm{mg} \mathrm{kg}^{-1} \mathrm{de}$ SNPs mostró una mayor actividad hipertiroidea e hipolipidímica en comparación con el control y la dosis de $200 \mathrm{mg} \mathrm{kg}^{-1}$.

Palabras clave: Nanopartículas; Hormona; Lípido; Tiroides; Colesterol.

\begin{abstract}
Impact of silver nanoparticles loaded with Ganoderma applanatum extract on thyroid and lipid profile of rat were studied. Synthesized SNPs (Average diameter $58.77 \mathrm{~nm}$; -13.8 mV zeta potential) were analysed by dynamic light scattering analysis. Fourier transform infrared spectroscopy provided broad and high transmission peak at $3248.12 \mathrm{~cm}^{-1}$ which indicates the loaded biochemical of the $G$. applanatum extract on the surface of SNPs. No mortality and behavioural changes were observed in the Acute toxicity test. Group-1 received $1 \mathrm{~mL}$ distilled water, group-2 and group-3 received $200 \mathrm{mg} \mathrm{kg}^{-1}$ and $400 \mathrm{mg} \mathrm{kg}^{-1}$ nanoparticles respectively. A $400 \mathrm{mg} \mathrm{kg}^{-1}$ dose of SNPs showed increased hyper thyroid and hypolipidimic activity as compared to control and $200 \mathrm{mg} \mathrm{kg}^{-1}$ dose.
\end{abstract}

Key words: Nanoparticles; Hormone; Lipid; Thyroid; Cholesterol. 


\section{Introduction}

Green nanotechnology is gaining ground in field of medical biology and great attention has been paid for preparation of materials of small size and the technology has entered into nanoscale range and application of nanotechnology has been incorporated in the field of material, chemical, biological sciences, and engineering (Nikam et al. 2014). Synthesis of nanoparticles and their application in different field of biological sciences and medicine has provided new a hope and dimension for development of nanodrugs lading to their effective delivery in the biological system (Shah et al. 2015). Nanotechnology refers to particles having size in the range of $1 \mathrm{~nm}$ to $100 \mathrm{~nm}$. The nanoparticles can be made up of carbon, metal oxides or organic matter and they have been used in drug delivery, bio detection of pathogens, tissue engineering, fluorescent biological labelling, tumour destruction, etc. (Salata 2004). The application of nanoparticles is increasing, since they have some specific properties such as ultra-small size, large surface to volume ratio, high reactivity and unique interactions with structural components which improve the pharmacokinetics and therapeutic index of the drugs (Kumar \& Sinha 2017).

Medicinal application of silver and its compound have been practicing since past 2000 years and they are nontoxic but efficient as bactericidal agent (Husen \& Siddiqi 2014). Recently, several physical and chemical methods of synthesis of silver nanoparticles have been developed but biological methods such as using plant and fungal material are quite easy owing to their less expensive, non-toxic and eco-friendly nature (Prabu \& Johnson 2015). Synthesis and application of nanoparticles mediated by different plant parts such as leaves, roots, flower, seeds etc. have widely been explored but synthesis of nanoparticles using fungal extract (specially woody fungi) and their applications is least explored (Sowmya et al. 2018).

Thyroid hormones are directly associated with metabolic regulation of body and modulate functions such as body weight, oxygen requirement, growth and development during childhood (Abbey et al. 2017) and patho-physiological dysfunction of thyroid gland is the most common endocrine disorder, about 42 million people suf- fering from thyroid associated diseases (Unnikrishnan \& Menon 2011). It has also been reported that serum cholesterol level increases in hypothyroidism and associated diseases, an enhance in the risks of coronary artery disease, atherosclerosis and heart failure has also been observed (Udovcic et al. 2017).

Ganoderma applanatum (Pers.) Pat. is a macrofungi belonging to genus Ganoderma $\mathrm{P}$. Karsten that have been traditionally used as medicine rather than as a food in China, Japan and India (Jeong et al. 2008). It is a polypore macrofungi with hard, woody, more or less fan-shaped, having semicircular, fruiting bodies with a dull and unvarnished outer surface with brownish to grayish-brown colour wrinkled zones of on carp surface, and white colour pore surface (Niemela $\&$ Miettinen 2008). A review of literature showed that $G$. applanatum is a comparatively less explored macrofungi for its medicinal importance. Thus an attempt to access the medical importance of the macrofungi is a novel approach; the aim of this work is to synthesise silver nanoparticles loaded with aqueous extract of G. applanatum and to study their impacts on thyroid and lipid profile of rat.

\section{Materials and methods}

\section{Collection of macrofungus and preparation of extract}

Fresh fruiting bodies of G. applanatum (Fig. 1) were collected from Kaziranga National Park of Assam $\left(26^{\circ} 30^{\prime}-26^{\circ} 45^{\prime} \mathrm{N}\right.$ to $\left.93^{\circ} 08^{\prime}-93^{\circ} 36^{\prime} \mathrm{E}\right)$ and matched and identified on the basis of morphology with museum specimen by Plant Identification \& Preservation Division of Department of Botany, Gauhati University, Assam where a voucher specimen (No. 833M) was deposited and the fruiting body of G. applanatum was brought to Department of Zoology, Ranchi University, Ranchi, for further study.

The fresh fruiting body of G. applanatum was initially washed with distilled water and then by absolute ethyl alcohol (99.8\%) to avoid microbial contamination. The fruiting bodies were dried in shade under room temperature for six to seven days, powdered and sieved. $50 \mathrm{~g}$ of the fine powder was subjected to aqueous extraction $(300 \mathrm{~mL}$ 
distilled water) using Soxhlet extraction unit. The extract obtained was filtered, concentrated and dried in a rotary flash evaporator maintained at $45^{\circ} \mathrm{C}$ for proper dehydration and the concentrated extract was stored in air tight black containers at room temperature for further studies. Freshly prepared aqueous extract was used for qualitative analysis of biochemicals (Arya et al. 2012).

\section{Synthesis of silver nanoparticles (SNPs)}

The synthesis of nanoparticle was carried out using a green method. The method is said green since it does not pose any harm to environment, or the workers, it is cheap and easy process. Synthesis of nanoparticles were done by mixing $3 \mathrm{~mL}$ (41 $\mathrm{mg} \mathrm{mL}^{-1}$ ) of $G$. applanatum fruiting body aqueous extract and $197 \mathrm{~mL}$ of $0.1 \mathrm{M}$ silver nitrate (169.87 $\mathrm{g} \mathrm{mol}^{-1}$ ) solution (i.e., $3.35 \mathrm{~g} \mathrm{AgNO}_{3} / 197$ $\mathrm{mL}$ of distilled water), the mixture was incubated at $80^{\circ} \mathrm{C}$ and was continuously using magnetic stirrer. The solution was pale yellow in the beginning but it turned to dark brown with time. The mixture was incubated until no further colour change was observed. Then the solution was cooled to room temperature and centrifuged at $27670 \mathrm{RCF}$ for 10 minutes. The supernatant was discarded and the pellet was washed three times with distilled water to discard any biochemical present in the solution but not bound to the nanoparticles (Dandapat et al. 2019).

\section{Characterization of $G$. applanatum extract loaded SNPs}

For UV-Visible spectra analysis, the sample was prepared by mixing $1 \mathrm{~mL}$ of nanoparticles solution in $4 \mathrm{~mL}$ of deionised water. $1 \mathrm{~mL}$ of diluted sample was taken in standard quartz cuvette and placed in sample compartment. UV-Visible spectra analysis was done by using Perkin Elmer Lambda-25 UV-Visible spectrophotometer (Perkin Elmer Inc., USA). The UV-Visible spectrophotometer was operated at $20 \pm 2{ }^{\circ} \mathrm{C}, 60-70 \%$ humidity and light test specification at 200-800 nm wave length.

Scanning electron microscopy (SEM) wad done to assess the size and shape of synthesized nanoparticle. SEM analysis was done using JEOL JSM-6390 LV (Japan) machine provided with Vega TC software. A thin layer of nanoparticles powder sample $(1 \mathrm{mg})$ was prepared on a glass slide and then pressed on a carbon taped copper grid for SEM. Excess powder on surface of carbon taped copper grid was blown away with compressed air and the SEM grid was allowed to dry by putting it under a mercury lamp for $5 \mathrm{~min}$ and was coated with platinum using ion sputter (Bini et al. 2018).

$\mathrm{X}$-ray diffraction analysis was done to assess the size of synthesized nanoparticles. X-ray diffraction analysis was carried out using a Rigakusmartlab diffraction XRD machine with $40 \mathrm{kV}$ operating voltage and $15 \mathrm{~mA}$ current, $\mathrm{Cu}-\mathrm{K} \alpha \mathrm{X}$ rays of wavelength $(\lambda)=1.54056 \AA$. Data were taken for the $2 \theta$ range of $10^{\circ}$ to $90^{\circ}$ with a step of $0.02^{\circ}$. The particle size was calculated by considering the peak at degrees by using Debye-Scherrer formula (Kumar \& Rao 2013):

$$
D=\frac{[0.9 \lambda]}{[\beta \cos \theta]}
$$

Where, ' $\lambda$ ' is wave length of $\mathrm{X}$-Ray $(0.1541$ $\mathrm{nm}$ ), ' $\beta$ ' is FWHM (full width at half maximum), ' $\theta$ ' is the diffraction angle and ' $D$ ' is particle diameter size.

Dynamic light scattering (DLS) analysis was done to assess the size of synthesized nanoparticles in terms of number, volume and intensity. For dynamic light scattering analysis the SNPs sample was diluted, filtered; and $0.1 \mathrm{mg} / \mathrm{mL}$ concentration of nanopaticle colloidal solution was ultrasonicated at $20 \%$ sonication amplitude with continuous mode during 882 second to avoid agglomeration and for proper dispersion of nanoparticles in the solution. The dynamic light scattering analysis and zeta-potential analysis of nanoparticles was carried out using Malvern Nano ZS green badge) ZEN3500 (U.K.) zetasizer provided with zetasizer Nano software (ZNUM, 2013).

Fourier transform infrared (FTIR) spectra analysis was done to detect the functional groups present in the biochemical substance loaded around the silver core of the nanoparticles. The analysis was carried out on IPRresting-21 (Shimadzu Corp., Kyoto, Japan) in the diffuse reflectance mode operated at a resolution of $4 \mathrm{~cm}^{-1}$ in the range of $400 \mathrm{~cm}^{-1}$ to $4000 \mathrm{~cm}^{-1}$ wave number and $\mathrm{KBr}$ as standard to identify the potential biomolecules present in fruiting body of $G$. applanatum extract which are responsible for reducing and capping the bioreduced silver nanoparticles. The FTIR instrument was operated at $25 \pm 5^{\circ} \mathrm{C}, 60-70 \%$ humidity (IMUSG, 2002). 


\section{Study of impact of G. applanatum extract loaded SNPs on rat}

Wistar albino rats of 175 to $200 \mathrm{~g}$ were obtained from the National Institute of Nutrition, Hyderabad, India. They were kept in cage and maintained under standard laboratory conditions at ambient room temperature $\left(22 \pm 3{ }^{\circ} \mathrm{C}\right)$ and relative humidity (30-65\%), with dark-light cycle of $12 \mathrm{~h}$ for 5 days. 40 rats were fed with a commercial pallet diet (Sadguru Shri Shri Industries Pvt. Ltd. Pune, India) and water. The experiment was performed after prior approval of the Animal Ethics committee of Ranchi University, Ranchi (Proceeding no. 46, page no. 137).

Acute toxicity study of $G$. applanatum extract loaded SNPs on rat was done according to OECD test guideline 425 (Up and Down procedure), the OECD guideline for acute toxicity emphasizes on reducing the number of animals to be used for acute toxicity tests. Test was performed for $2000 \mathrm{mg} \mathrm{kg}^{-1}$ dose on rats according to the body weight. 10 rats were equally divided among 2 groups (five rats in each group-A and group-B) were fasted (3-4 hours) prior to dosing but were accessed with water ad libitum. Single dose $(2000 \mathrm{mg} / \mathrm{kg})$ of vehicle as well SNPs were fed by feeding gavage rats of group-A and group -B respectively. The rats were provided with food and water ad libitum after 2hours of treatment. After single dose at first day, the rats were further not treated with vehicle and nanoparticles and they were observed for 30 minutes, 4 hours, 24 hours and till the end of $14^{\text {th }}$ day for behavioural changes and death due to toxicity (Saleem et al. 2017).

- Group A: Rats of this group were fed single dose of vehicle (distilled water $2000 \mathrm{mg} \mathrm{kg}^{-1}$ body weight).

- Group B: Rats of this group were fed single dose (2000 mg kg-1 body weight) G. applanatum extract mediated silver nanoparticles.

No toxicity was observed up to $2000 \mathrm{mg} \mathrm{kg}^{-1}$ of both vehicle (distilled water) and silver nanoparticle loaded with aqueous extract of $G$. applanatum.

The impacts of G. applanatum extract loaded SNPs on thyroid and lipid profile of rats were analysed by chemiluminescence immune assay (Demers \& Spencer 2006) and spectrophotometric method (Rifa \& Warnick 2006). For the study of impacts of G. applanatum extract loaded SNPs on thyroid and lipid profile of rats seven days experimental period (Garba et al. 2009). Fifteen rats were distributed into three groups each containing 5 rats. Two doses of SNPs (high dose: $400 \mathrm{mg} \mathrm{kg}^{-1}$ and low dose: $200 \mathrm{mg} \mathrm{kg}^{-1}$ ) were taken and the doses were administered according to the body weight of the animals (Oghenesuvwe et al. 2014). The experiment designed employed is as follows

- Group 1: Rats served as control and were not treated with nanoparticles. They received single dose $(1 \mathrm{~mL})$ of distilled water (vehicle) daily orally for 7 days.

- Group 2: Rats of this group received daily single dose (200 $\mathrm{mg} \mathrm{kg}^{-1}$ body weight) of nanoparticles orally for 7 days.

- Group 3: Rats of this group received daily single dose (400 $\mathrm{mg} \mathrm{kg}^{-1}$ body weight) of nanoparticles orally for 7 days.

At the end of experimental period ( $8^{\text {th }}$ day) animals were lightly euthanized using diethyl ether, and blood was collected from rats by retro-orbital sinus blood collection method into evacuated vials (SRL Diagnostic Pvt. Ltd.) containing clotting activator. Collected blood samples were allowed to clot and then centrifuged at 2000-2500 rpm and the serum was collected within 45 minutes of collection of blood samples. Serum samples were kept at $4{ }^{\circ} \mathrm{C}$ for analyses of lipid and thyroid profiles.

Estimation of serum lipid parameters were done on a semi automatic chemistry analyzer: SACA-19100 (MRC Ltd., Israel) operated at 0-40 ${ }^{\circ} \mathrm{C}, \leq 85 \%$ relative humidity using the diagnostic reagent kit by DiaSys International Pvt. Ltd. (Holzheim, Germany). Analyses of serum cholesterol parameters were done using diagnostic reagent kit by DiaSys international Pvt. Ltd. (Holzheim, Germany). Total cholesterol was measured by using Cholesterol FS* kit (Cat. No. 113009910023), high density lipoprotein cholesterol (HDL-C) was measured by HDL-C Immuno FS* kit (Cat. No. 135219910 023), low density lipoprotein cholesterol (LDL-C) was measured by LDL-C Select FS* kit (Cat. No. 141219910 026) and triglyceride was measured by Triglycerides FS* kit (Cat. No. 157109910021).

The impact of SNPs on thyroid profile was studied on the basis of estimation of serum total triiodothyronine $\left(\mathrm{T}_{3}\right)$, thyroxine $\left(\mathrm{T}_{4}\right)$ and thyroidstimulation hormone (TSH) by by using semiautomated chemiluminescence (CLIA) plate ana- 
lyzer (Semi Auto Chemilumi Basic CLIA 2096 plus, Analytical Technologies Limited, Gujarat, India) operated at 10 to $40{ }^{\circ} \mathrm{C}$ within $15-75 \%$ humidity. The assay was performed by using thyroid function CLIA kits (total $\mathrm{T}_{3}$ : CL1001-2, total $\mathrm{T}_{4}$ : CL1002-2 and TSH: CL1003-2) were obtained from Suyog diagnostic Pvt. Ltd. Kolkata, India.

Statistical analysis: Entire statistical works were done using statistical software WinSTAT (R. Fitch Software, Canal Park, Cambridge, Massachusetts, USA). Data were taken $(\mathrm{N}=5)$ and results were expressed as a mean \pm standard error of mean. Statistical analysis was performed by one-way ANOVA with post-hoc student's t-test, $\mathrm{p}$ $\leq 0.05$ was considered as statistically significant.

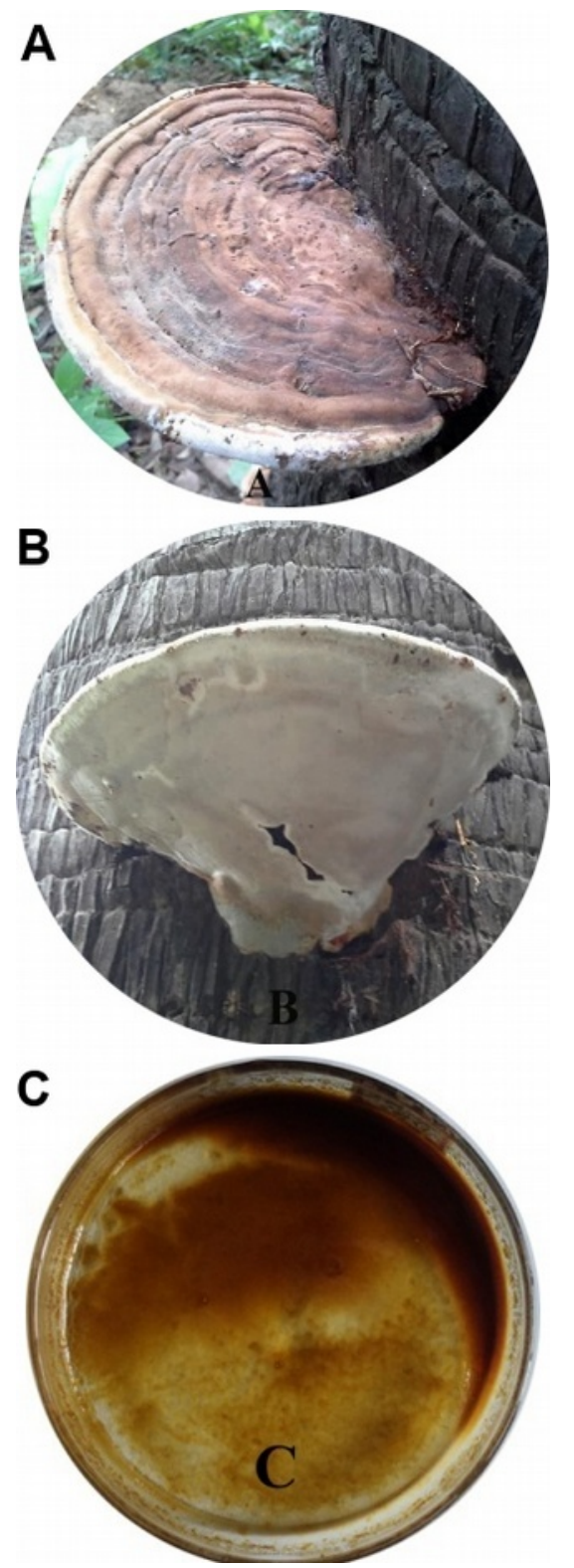

Figura 1. A, B: Cuerpo fructífero de G. applanatum; C: extracto. Figure 1. A, B: Fruiting body of G. applanatum; C: extract.

\section{Results}

\section{Biochemical analysis of G. applanatum}

The biochemical analysis of crude extract of $G$. applanatum (Fig. 1) is presented in the table 1. The biochemical analyses showed the presence of carbohydrate, protein, alkaloid, flavonoid, saponins, steroid, phenolics and some other biochemicals in the aqueous extract (Table 1).

\section{Synthesis of silver nanoparticles}

Synthesis of silver nanoparticles mediated by aqueous extract of $G$. applanatum is presented in the figure 2. A gradual change in colour from pale yellow colour to dark brown was observed and this change is an accepted indication that the reaction is happening between the biochemicals and the silver ions present in the solution.

\begin{tabular}{|l|c|}
\hline Mycochemicals & Present(+) / Absent (-) \\
\hline Carbohydrate & + \\
\hline Glycosides & + \\
\hline Protein & + \\
\hline Alkaloid & + \\
\hline Steroid & + \\
\hline Triterpene & + \\
\hline Flavonoid & + \\
\hline Tannin & + \\
\hline Lipid & + \\
\hline Saponin & + \\
\hline
\end{tabular}

Tabla 1. Análisis de micoquímicos presentes en el extracto acuoso del cuerpo fructífero de G. applanatum.

Table 1. Analysis of proximate mycochemicals present in aqueous fruiting body extract of $G$. applanatum.

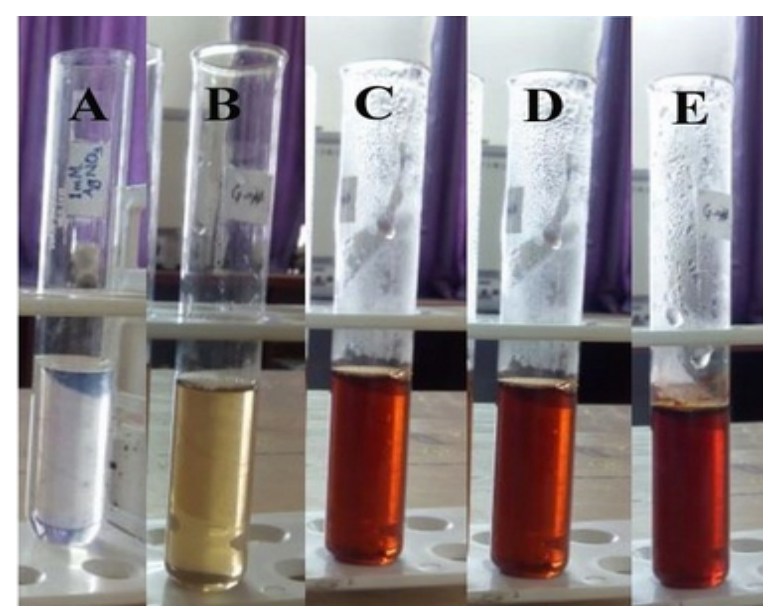

Figura 2. A: Solución $\mathrm{AgNO}_{3}$; B: Solución mixta $\mathrm{AgNO}_{3}$ y extracto de G. applanatum; C: Después de $30 \mathrm{~min}$; D: Después de 1 hora; E: Después de 2 horas.

Figure 2. A: $\mathrm{AgNO}_{3}$ solution; B: Mixed solucion $\mathrm{AgNO}_{3}$ and $G$. applanatum extract; C: After $30 \mathrm{~min}$; D: After 1 hour; C: After 2 hours (E). 


\section{Characterization of nanoparticles}

The absorption spectrum of nanoparticles obtained from UV-visible spectroscopy is presented in the figure 3. The UV-visible spectrum showed a peak at $400 \mathrm{~nm}$, that corresponds to the surface plasmon resonance of the synthesized SNPs reported in previous work (Englebienne et al. 2012).

The result of SEM (Scanning electron microscopy) analysis is presented in the figure 4 . The result clearly reveals that the synthesized nanoparticles are spherical in shaped and with a size in the 70 to $120 \mathrm{~nm}$ in diameter. In general it is not possible to measure the size of particles using SEM, but here we are using the software provided with the SEM instrument to measure the size of the synthesized nanoparticles. The software enables us to measure the size of particles live while exploring the field.

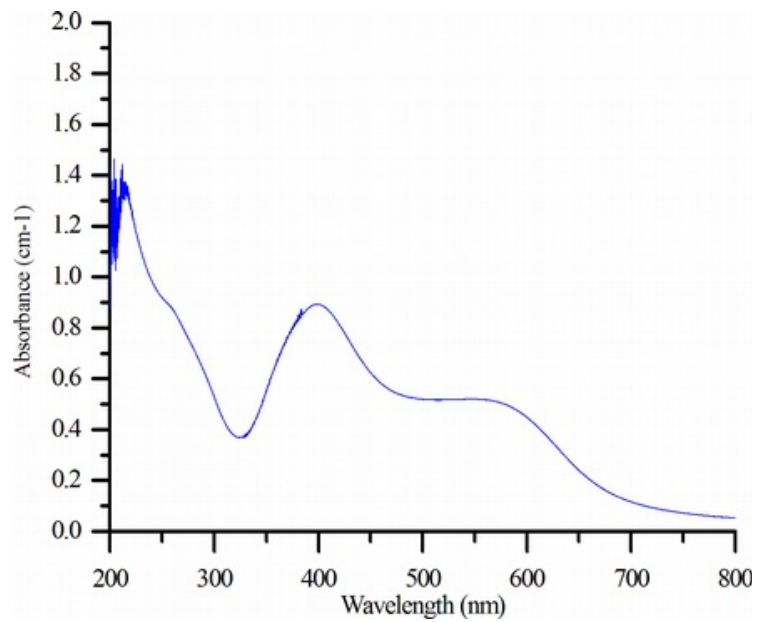

Figura 3. Espectro UV-visible de las nanopartículas de plata sintetizadas mediante extracto acuoso del cuerpo fructífero de $G$. applanatum.

Figure 3. UV-Visible spectrum of synthesized silver nanoparticles mediated by aqueous fruiting body extract of G. applanatum.

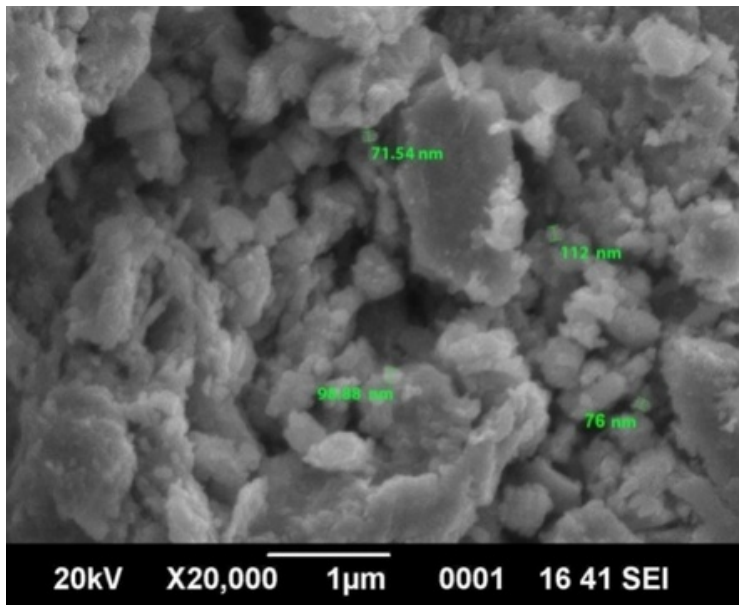

Figura 4. Imagen de microscopio electrónico de barrido de las nanopartículas de plata sintetizadas mediante extracto acuoso del cuerpo fructífero de G. applanatum.

Figure 4. Scanning electron microscopy photograph of synthesized silver nanoparticles mediated by aqueous fruiting body extract of G. applanatum.

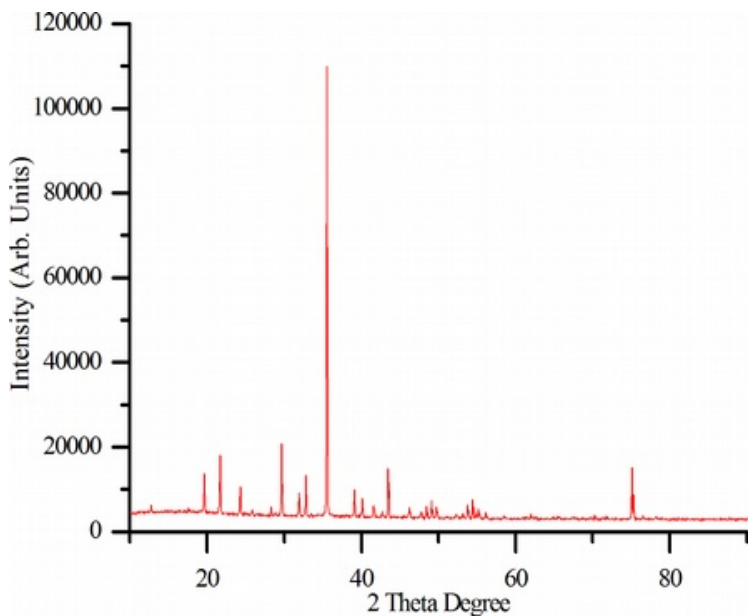

Figura 5. Picos de difracción de rayos $\mathrm{X}$ de las nanopartículas de plata del extracto de G. applanatum.

Figure 5. X-Ray diffraction peaks of G. applanatum extract mediate silver nanoparticles powder.

\begin{tabular}{|c|c|c|c|c|c|c|c|c|}
\hline \multicolumn{9}{|c|}{ Copper $\mathrm{K}$ radiation: Wavelength $\lambda(\mathrm{nm})=0.154$} \\
\hline $\begin{array}{c}2 \theta \text { of the major } \\
\text { peaks (deg.) }\end{array}$ & $\begin{array}{c}\theta \text { of the } \\
\text { peaks (deg.) }\end{array}$ & $\begin{array}{c}\text { d-spacing } \\
(\AA)\end{array}$ & \begin{tabular}{|c|} 
Intensity \\
(cps)
\end{tabular} & $\begin{array}{l}\text { FWHM of major } \\
\text { peaks ( } \beta \text { : deg.) }\end{array}$ & $\begin{array}{c}\text { FWHM of the major } \\
\text { peaks ( } \beta \text { : rad.) }\end{array}$ & Size (A) & Size $(n m)$ & $\begin{array}{c}\text { Avg. Size } \\
\text { (nm) }\end{array}$ \\
\hline 35.51 & 17.75 & 2.52581 & 9732.26 & 0.0796 & 0.0013 & 1093.7 & 109.37 & 102.08 \\
\hline 29.66 & 14.83 & 3.00943 & 1690.34 & 0.0732 & 0.0012 & 1171.7 & 117.17 & \\
\hline 21.73 & 10.86 & 4.08588 & 1652.76 & 0.1393 & 0.0024 & 606.0 & 60.60 & \\
\hline 75.09 & 37.54 & 1.26401 & 1411.44 & 0.0863 & 0.0015 & 1211.9 & 121.19 & \\
\hline
\end{tabular}

Tabla 2. Estimación del tamaño medio de las nanopartículas del extracto de G. applanatum, empleando el análisis de difracción de rayos X y la fórmula de Scherrer.

Table 2. Average size estimation of G. applanatum extract mediated nanoparticles using X-ray diffraction analysis and Scherrer formula. 
The X-ray diffraction pattern of the $G$. applanatum extract mediated synthesized silver nanoparticles is presented in the table 2 and the figure 5. The results show that the size of particles formed is between 60.60 and $121.19 \mathrm{~nm}$, with average particle size of $102.08 \mathrm{~nm}$.

Dynamic light scattering (DLS) analysis provided the size distribution in terms of intensity, volume and number of the synthesized SNPs, the result have been presented in the figure 6 . The figure $6 \mathrm{~A}$ (particle size distribution by intensity) represents high peak for nanoparticles of $77.25 \mathrm{~nm}$ diameter with $99.6 \%$ intensity and small peak for
$5177 \mathrm{~nm}$ diameter nanoparticles with 3.4\% intensity. The figure $6 \mathrm{~B}$ (particle size distribution by volume) represents high peak and low peak for nanoparticles of $88.4 \%$ and $11.3 \%$ size distribution by volume of $38.21 \mathrm{~nm}$ and $5282 \mathrm{~nm}$ diameter nanoparticles respectively. The figure $6 \mathrm{C}$ (particle size distribution by number) represents single peak for nanoparticles of diameter of $23.64 \mathrm{~nm}$ with $100 \%$ size distribution by number. DLS analysis also provides the zeta potential of synthesized nanoparticles. The zeta potential of synthesized nanoparticles $(-13.8 \mathrm{mV})$ is presented in the figure 7.
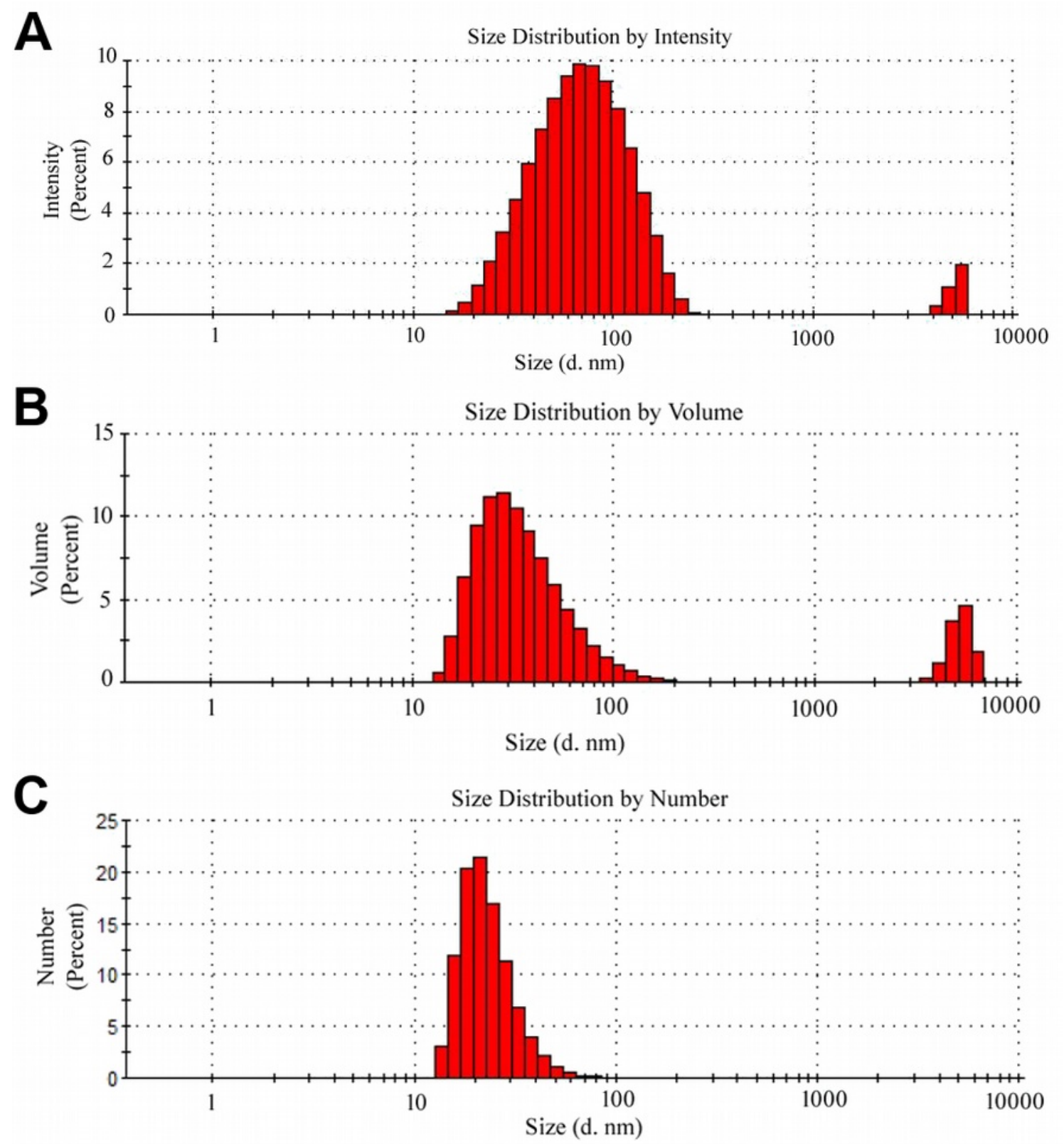

Figura 6. Distribución del tamaño de las nanopartículas. A: Por intensidad; B: Por volumen; C: Por número. Figure 6. Size distribution of nanoparticles. A: By intensity; B: By volume. C: By number. 


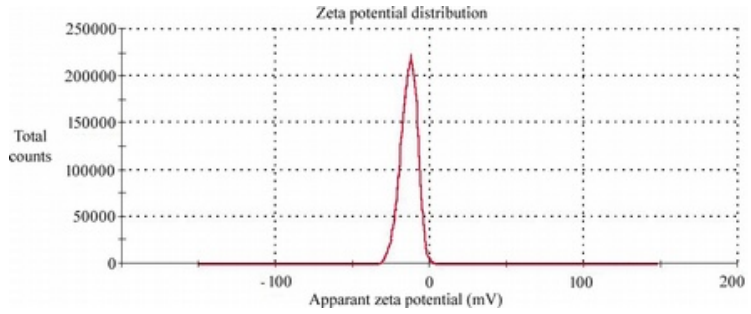

Figura 7. Distribución de potencial $\mathrm{Z}$ de las naopartículas.

Figure 7. Zeta potential distribution of nanoparticles.

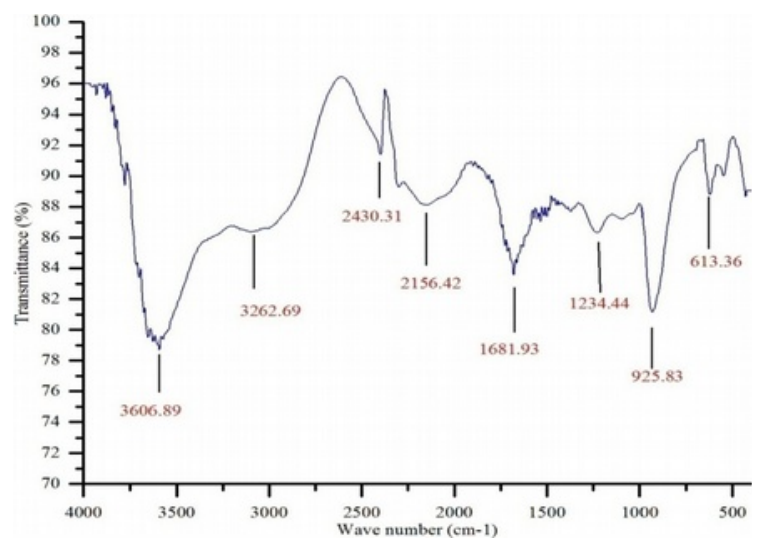

Figura 8. Análisis IR-TF de las nanopartículas de plata del extracto de G. applanatum.

Figure 8. FTIR analysis of G. applanatum extract mediated silver nanoparticles.

The result of FTIR spectroscopy analysis of synthesized nanoparticles is presented in the figure 8 . The result represents absorption peaks at $3606 \mathrm{~cm}^{-1}$ corresponds to O-H stretch for alcohol and phenol, $2430 \mathrm{~cm}^{-1}$ corresponds to N-H stretch for primary and secondary amines, $2156 \mathrm{~cm}^{-1}$ corresponds to $\mathrm{C} \equiv$ stretch for alkynes, $1681 \mathrm{~cm}^{-1}$ corresponds to $\mathrm{C}=\mathrm{N}$ for amines or $\mathrm{C}=\mathrm{O}$ stretch for unsaturated aromatic carboxylic acid, $1234 \mathrm{~cm}^{-1}$ corresponds to $\mathrm{C}-\mathrm{O}$ stretch for aromatic com- pound, $1091 \mathrm{~cm}^{-1}$ corresponds to C-F stretch presented fluroalkanes, $925 \mathrm{~cm}-1$ corresponds to $\mathrm{C}=\mathrm{C}$ stretch presented alkanes and also stretch for $\mathrm{O}-\mathrm{H}$ and $613 \mathrm{~cm}^{-1}$ corresponds to $\mathrm{C}-\mathrm{Cl}$ or $\mathrm{C}-\mathrm{Br}$ stretch for chloro and bromo alkanes.

\section{Acute toxicity study}

Results of acute toxicity study of SNPs loaded with $G$. applanatum extract is presented in the table 3. The results showed no toxic symptom such as salivation, convulsion and tremor, itching, redness of eyes, hair loss, behavioural changes, coma and death in rats treated with $2000 \mathrm{mg} \mathrm{kg}^{-1}$ dose of SNPs.

\section{Impact of SNPs loaded with G. applanatum extract on thyroid profile of rat}

The result of impacts of SNPs loaded with G. applanatum extract on thyroid profile of rats is presented in the table 4 . The result showed that both $200 \mathrm{mg} \mathrm{kg}^{-1}$ and $400 \mathrm{mg} \mathrm{kg}^{-1}$ doses of SNPs significantly $(\mathrm{p} \leq 0.05)$ increased triiodothyronine $\left(\mathrm{T}_{3}\right)$ concentration (Group 2: $60.60 \pm 1.38 \mathrm{ng} \mathrm{dL}^{-1}$; Group3: $\left.76.40 \pm 0.94 \mathrm{ng} \mathrm{dL}^{-1}\right)$ as compared to control $\left(30.20 \pm 1.01 \mathrm{ng} \mathrm{dL}^{-1}\right)$. Similarly 200 and $400 \mathrm{mg} \mathrm{kg}^{-1}$ doses of SNPs also significantly $(\mathrm{p} \leq 0.05)$ increased the concentration of thyroxin $\left(\mathrm{T}_{4}\right)$ in rats (Group2: $4.56 \pm 0.10 \mu \mathrm{g} \mathrm{dL}^{-1}$; Group3: $\left.6.60 \pm 0.21 \mu \mathrm{g} \mathrm{dL}^{-1}\right)$ compared to control group $\left(2.94 \pm 0.08 \mu \mathrm{g} \mathrm{dL}^{-1}\right)$. A significant $(\mathrm{p} \leq 0.05)$ decrease in thyroid stimulating hormone (TSH) was observed in rats of Group-2 $(0.67 \pm 0.008 \mu \mathrm{IU}$ $\left.\mathrm{mL}^{-1}\right)$ and Group-3 $(0.26 \pm 0.01 \mu \mathrm{IU} \quad \mathrm{mL}-1)$ treated with 200 and $400 \mathrm{mg} \mathrm{kg}^{-1}$ doses of SNPs respectively, compared to control Group-1 (TSH: $\left.0.87 \pm 0.01 \mu \mathrm{IU} \mathrm{mL} \mathrm{m}^{-1}\right)$.

\begin{tabular}{|c|c|c|c|c|c|c|c|c|c|c|c|c|}
\hline \multirow[b]{3}{*}{ Parameters } & \multicolumn{12}{|c|}{ Treatment groups } \\
\hline & \multicolumn{4}{|c|}{ Group-1 } & \multicolumn{4}{|c|}{ Group-2 } & \multicolumn{4}{|c|}{ Group-3 } \\
\hline & $30 \mathrm{~min}$ & $4 \mathrm{~h}$ & $24 \mathrm{~h}$ & 14 day & $30 \mathrm{~min}$ & $4 \mathrm{~h}$ & $24 \mathrm{~h}$ & 14 day & $30 \mathrm{~min}$ & $4 \mathrm{~h}$ & $24 \mathrm{~h}$ & 14 day \\
\hline Fur \& skin & $\mathrm{N}$ & $\mathrm{N}$ & $\mathrm{N}$ & $\mathrm{N}$ & $\mathrm{N}$ & $\mathrm{N}$ & \begin{tabular}{|l|}
$\mathrm{N}$ \\
\end{tabular} & $\mathrm{N}$ & $\mathrm{N}$ & $\mathrm{N}$ & \begin{tabular}{|l|}
$\mathrm{N}$ \\
\end{tabular} & $\mathrm{N}$ \\
\hline Eyes & $\mathrm{N}$ & $\mathrm{N}$ & $\mathrm{N}$ & $\mathrm{N}$ & $\mathrm{N}$ & $\mathrm{N}$ & $\mathrm{N}$ & $\mathrm{N}$ & $\mathrm{N}$ & $\mathrm{N}$ & $\mathrm{N}$ & $\mathrm{N}$ \\
\hline Salivation & $\mathrm{N}$ & $\mathrm{N}$ & $\mathrm{N}$ & $\mathrm{N}$ & $\mathrm{N}$ & $\mathrm{N}$ & $\mathrm{N}$ & $\mathrm{N}$ & $\mathrm{N}$ & $\mathrm{N}$ & $\mathrm{N}$ & $\mathrm{N}$ \\
\hline Breathing & $\mathrm{I}$ & $\mathrm{N}$ & $\mathrm{N}$ & $\mathrm{N}$ & I & $\mathrm{N}$ & $\mathrm{N}$ & $\mathrm{N}$ & I & $\mathrm{N}$ & $\mathrm{N}$ & $\mathrm{N}$ \\
\hline Somatomotor activity \& behavior pattern & $\mathrm{N}$ & $\mathrm{N}$ & $\mathrm{N}$ & $\mathrm{N}$ & $\mathrm{N}$ & $\mathrm{N}$ & $\mathrm{N}$ & $\mathrm{N}$ & $\mathrm{N}$ & $\mathrm{N}$ & $\mathrm{N}$ & $\mathrm{N}$ \\
\hline Sleep & $\mathrm{N}$ & $\mathrm{N}$ & $\mathrm{N}$ & $\mathrm{N}$ & $\mathrm{N}$ & 1 & $\mathrm{~N}$ & $\mathrm{~N}$ & $\mathrm{I}$ & $\mathrm{N}$ & $\mathrm{N}$ & $\mathrm{N}$ \\
\hline Convulsions \& tremors & NF & NF & NF & NF & NF & NF & $\mathrm{NF}$ & NF & NF & NF & NF & NF \\
\hline Itching & NF & NF & NF & NF & NF & NF & NF & NF & NF & NF & NF & NF \\
\hline Coma & NF & NF & NF & NF & NF & NF & NF & NF & NF & NF & NF & NF \\
\hline Death & NF & NF & NF & NF & NF & NF & NF & NF & NF & NF & NF & NF \\
\hline
\end{tabular}

$N=$ normal, $I=$ increased,$N F=$ not found

Tabla 3. Efectos tóxicos agudos y patrones de comportamiento de grupos de ratas tratadas con nanopartículas cargadas con extracto de $G$. applanatum, a lo largo del tiempo.

Table 3. Acute toxic effects and behavioral patterns of groups of rats treated nanoparticles loaded with G. applanatum extract, along the time. 


\begin{tabular}{|c|c|c|c|}
\hline & \multicolumn{3}{|c|}{ Treatment groups } \\
\hline Parameters & Group-1 & Group-2 & Group-3 \\
\hline $\begin{array}{l}\text { Triiodothyronine }\left(\mathrm{T}_{3}\right) \\
\text { ng dL }^{-1}\end{array}$ & $30.20 \pm 1.01$ & $60.60 \pm 1.38^{*}$ & $76.40 \pm 0.94$ * \\
\hline $\begin{array}{l}\text { Thyroxine }\left(\mathrm{T}_{4}\right) \\
\mathrm{\mu g} \mathrm{dL}^{-1}\end{array}$ & $2.94 \pm 0.08$ & $4.56 \pm 0.10^{*}$ & $6.60 \pm 0.21^{*}$ \\
\hline $\begin{array}{l}\text { Thyroid stimulating } \\
\text { hormone }(\mathrm{TSH}) \\
\mu \mathrm{IU} \mathrm{mL}^{-1}\end{array}$ & $0.87 \pm 0.01$ & $0.67 \pm 0.008^{*}$ & $0.26 \pm 0.01^{*}$ \\
\hline
\end{tabular}

Tabla 4. Efecto de las nanopartículas de plata del extracto de $G$. applanatum sobre el perfil de tiroides de ratas.

Table 4. Effect of silver nanoparticles loaded with G. applanatum extract on thyroid profile of rats.

\section{Impact of SNPs loaded with G. applanatum extract on lipid profile of rat}

The result of impacts of SNPs loaded with G. applanatum extract on lipid profile of rats is presented in the table 5. The result showed $200 \mathrm{mg}$ $\mathrm{kg}^{-1}$ dose of SNPs significantly decrease LDL cholesterol $\left(31.02 \pm 1.13 \mathrm{mg} \mathrm{dL}^{-1}\right)$, triglyceride $\left(52.05 \pm 1.87 \mathrm{mg} \mathrm{dL}^{-1}\right)$, and total cholesterol $\left(66.00 \pm 0.50 \mathrm{mg} \mathrm{dL}^{-1}\right)$ compared to control Group 1 of rats (LDL-C: $39.63 \pm 0.69 \mathrm{mg} \mathrm{dL}^{-1}$; triglyceride: $119.44 \pm 1.14 \mathrm{mg} \mathrm{dL}^{-1}$; total cholesterol: $\left.79.37 \pm 0.70 \mathrm{mg} \mathrm{dL}^{-1}\right)$. Statistically no significant difference was observed in HDL cholesterol level of group-2 and group-1. $400 \mathrm{mg} \mathrm{kg}{ }^{-1}$ dose of SNPs showed high hypolipidimic activity compared to low dose of SNPs and significantly decreased total cholesterol $\left(50.33 \pm 0.70 \mathrm{mg} \mathrm{dL}^{-1}\right)$, LDL cholesterol $\left(26.04 \pm 0.68 \mathrm{mg} \mathrm{dL}^{-1}\right)$, triglyceride $\left(47.05 \pm 1.80 \mathrm{mg} \mathrm{dL}^{-1}\right)$, but a significant increase in HDL cholesterol level $(64.40 \pm 0.66 \mathrm{mg}$ $\mathrm{dL}^{-1}$ ) was observed compared to control (HDL-C: $\left.46.35 \pm 0.69 \mathrm{mg} \mathrm{dL}^{-1}\right)$.

\begin{tabular}{|l|c|c|c|}
\cline { 2 - 4 } \multicolumn{1}{c|}{} & \multicolumn{3}{c|}{ Treatment groups } \\
\hline \multicolumn{1}{c|}{ Parameters } & Group-1 & Group-2 & Group-3 \\
\hline $\begin{array}{l}\text { Total cholesterol } \\
\mathrm{mg} / \mathrm{dL}\end{array}$ & $79.37 \pm 0.70$ & $66.00 \pm 0.50^{\star}$ & $64.40 \pm 0.66^{*}$ \\
\hline $\begin{array}{l}\mathrm{HDL} \text { cholesterol } \\
\mathrm{mg} / \mathrm{dL}\end{array}$ & $46.35 \pm 0.69$ & $48.12 \pm 0.62$ & $50.33 \pm 0.70^{*}$ \\
\hline $\begin{array}{l}\mathrm{LDL} \text { cholesterol } \\
\mathrm{mg} / \mathrm{dL}\end{array}$ & $39.63 \pm 0.69$ & $31.02 \pm 1.13^{*}$ & $26.04 \pm 0.68^{*}$ \\
\hline Triglyceride $\mathrm{mg} / \mathrm{dL}$ & $119.44 \pm 1.14$ & $52.05 \pm 1.87^{*}$ & $47.05 \pm 1.80^{*}$ \\
\hline
\end{tabular}

Tabla 5. Efecto de las nanopartículas de plata del extracto de $G$. applanatum sobre el perfil lipídico de ratas.

Table 5. Effect of silver nanoparticles loaded with G. applanatum extract on lipid profile of rats

\section{Discussion}

Mushroom or macrofungus species possess high antioxidant activity due to the presence of compounds possessing antioxidant biocompounds such as a phenolics, organic acids, alkaloids etc. Thus, macrofungi can be used as a natural antioxidant supplement and in the pharmaceutical industry for the production of antioxidants (Dandapat \& Sinha 2015). It has been reported that species of Ganoderma contain different mycochemical such as polysaccharides, proteins, amino acids, fatty acids, terpenoids, steroids, alkaloids, phenolic compounds, etc (Singh et al. 2014). In the present study Ganoderma applanatum extract showed the presence of different types of biochemicals and thus possesses strong antioxidant activity. It has been reported that mycochemicals such as phenols, flavonoids and tannins etc. possess antioxidant activity (Dandapat et al. 2018). In the present study after mixing of aqueous extract of $G$. applanatum with silver nitrate, a gradual colour change from pale yellow to dark brown colour was observed while incubating (Fig. 2), this colour change indicates that reaction between silver ion and mycochemicals is happening and particles are being synthesized, but to determine the size of synthesized particles, characterization is required (Firdhouse et al. 2012).

In nanotechnology UV-visible spectroscopy is used to monitor the SPR of SNPs. The absorption spectrum of nanoparticles obtained from UV-visible absorption spectroscopy is presented in figure 3, which showed peak at $400 \mathrm{~nm}$ corresponds to the surface plasmon resonance of the synthesized SNPs (Englebienne et al. 2012). Previous studies reported formation and stability of silver nanoparticles mediated by extracts from biological sources such as plants and fungi show maximum absorption 400-500 $\mathrm{nm}$ which correspond to the size of nanoparticles under $100 \mathrm{~nm}$ (Gujral 2015). In previous work variable UV-visible spectra peaks were observed for synthesized silver nanoparticles from different mushroom extracts and reported the SPR for synthesized silver nanoparticles at $420 \mathrm{~nm}$ for Ganoderma lucidum (Curtis) P. Karst. and Agaricus bisporus (J. E. Lange) Imbach, however the SPR for absorption spectra of Pleurotus ostreatus (Jacq.) P. Kumm. (as Pleurotus florida) and Pleurotus platypus Sacc. mediated silver nanoparticles were $435 \mathrm{~nm}$ and $300 \mathrm{~nm}$. It has been reported by many workers that a surface plasmon resonance between $350-450 \mathrm{~nm}$ is obtained when the size of synthesized nanoparticles is below $100 \mathrm{~nm}$. Any deviation from this range indicates that the silver particles formed are not in the nano range (Sujatha et 
al. 2013). In the present study, absorption peak at $400 \mathrm{~nm}$ of silver nanoparticles sample obtained by UV-visible spectroscopy analysis (Fig. 3) corresponds to SPR reported by previous works and indicates that the synthesized silver particles are in the nano range, i.e. below $100 \mathrm{~nm}$ in size and hence are nanoparticles.

Scanning electron microscopy of synthesized SNPs (71 to $112 \mathrm{~nm}$ ) loaded with $G$. applanatum extract (Fig. 4) compared with previous report of SNPs loaded with Boswellia ovalifoliolata N. P. Balakr. \& A. N. Henry extract and found the SNPs are spherical shaped, 30-40 nm diameter (Gurunathan et al. 2014). The result of present study provided the satisfactory evidence when compared with the size and shape of SNPs loaded with $B$. ovalifoliolata extract mentioned in previous study.

X-Ray diffraction pattern of a powder sample is considered to be the fingerprint of that sample (Brady et al. 1995). The information pertaining to phase formation, translational symmetry present and size and shape of the unit cell are obtained from peak positions in the diffraction pattern of a sample. In present study, G. applanatum extract mediated SNPs (Fig. 5 and Table 2) were screened to have average particle size of $102.08 \mathrm{~nm}$ and consisted of the major peaks of silver nanoparticles with a fcc (face cubic centered) type lattice. Some additional unassigned peaks were also observed, which may be due to presence of nonbonded mychochemicals present with the powder (Kumar \& Rao 2013). Mohanta et al. (2018) synthesized SNPs mediated by from Ganoderma sessiliforme Murrill extract. XRD-analysis indicates that the average size of synthesized nanparticles was $45.26 \mathrm{~nm}$. The result of present study correlates with the previous XRD analysis of SNPs.

Dynamic light scattering (DLS) is also known as photon correlation spectroscopy (PCS) and has been widely used for analysis of nanoparticles size in liquid phase (Phenrat et al. 2009). The result of DLS analysis of nanoparticles in terms of distribution by intensity in the colloidal solution depends upon the rate of fluctuation of intensity of the laser beam by the particles of different size (Nanocomposix 2015). Fluctuation of intensity corresponds to constant motion of particles which is due to Brownian motion, i.e. quick motion small particles and slow motion of large particles in liquid environment due to random collision among them and provides fundamental size of the nanoparticles (ZNUM 2013). The DLS size distribution by volume analysis of nanoparticles represents the total volume of particles of different size bins. The DLS size distribution by number analysis of nanoparticles represents the total number of particles of different size bins (Nanocomposix, 2015). In the present study, average size of synthesized SNPs was $58.77 \mathrm{~nm}$ in diameter (Fig. 6) and the synthesized nanoparticles reflected their size with the materials of nanoscale range.

Zeta potential is the electrostatic charge distribution, which develops in liquid layer or capping materials on surface (stern layer) of the nanoparticles and diffuse layer present outside the stern layer which impacts the potential stability of the particles in a colloidal system (Bhattacharjee2016). Zeta potential of nanoparticles within between $-25 \mathrm{mV}$ to $+25 \mathrm{mV}$ provides efficiency of the capping material to stabilize the nanoparticles in colloid solution and their even distribution in the solution (Almeida et al. 2015). In the present study, the Zeta potential of synthesized nanoparticles was $-13.8 \mathrm{mV}$, this indicates the stability of synthesized silver nanoparticles in the solution (Fig. 7).

FTIR analysis provides confirmation of presence of biomolecules by analysis of functional groups and provides the confirmation of capping tendency of therapeutic molecules of biological extracts present on the surface of synthesized nanoparticles (Kumar et al. 2014). Gurunathan et al. (2014) synthesized gold nanoparticles loaded with G. lucidum extract, they performed FTIR analysis and reported strong bands of FTIR spectra at 602, 1096, 1201, 1388, and $1636 \mathrm{~cm}^{-1}$ which correspond to the amide polypeptides or proteins and indicates their presence as capping agent in AuNPs. FTIR spectra analysis of crude extract of G. lucidum was done and reported that the FTIR spectrum peaks for biochemicals such as terpenoids and polysaccharide at 1150 to $1000 \mathrm{~cm}^{-1}$ and 1760 to $1600 \mathrm{~cm}^{-1}$ corresponds to terpenoids, polysaccharide and carbonyl compounds (Zhu \& Tan 2015). In the present study the FTIR peaks of SNPs loaded with G. applanatum extract (Fig. 8) also provided the confirmation about functional groups of biochemicals such as phenols, amines and other compounds of extracts which acts as capping agents (Gurunathan et al. 2014). The FTIR analysis makes clear that the nanoparticles are surrounded (capped) by the biomolecules present in the aqueous extract, thus 
the nanoparticles can be declared to be loaded with mycochemicals present in the aqueous extract of G. applanatum.

According to World Health Organization application of herbs and mushrooms for the therapy of diseases ethnomedicinally should be evaluated and explored for health safety and toxic effects (Ogbonnia et al. 2010). Previously it has been reported that woody mushrooms and metal nanoparticles are toxic to animals (Wang et al. 2017). Although, G. applanatum has valuable pharmacological effects and lack toxicity. It has been reported that, acute oral toxicity study is necessary to determine the safer dose range to manage the clinical signs and symptoms of the drugs (Saleem et al. 2016) and the toxic outcomes of drugs such as clinical signs and symptoms which are principal observations among various toxicity indicators should also be studied (Subramanion et al. 2011) In the present study, SNPs loaded with extract did not show any mortality and acute toxicity symptoms (Table 3 ) in animal till 14 days. Increased in respiration and sleeping was observed in rats after treatment up to 30 minutes. An increase in breathing and sleeping within 30 minutes from treatment were associated with short-term stress in rats (Hirotsu et al. 2015). Thus, SNPs loaded with $G$. applanatum extract was found to be non-toxic and then used for the study of impact of SNPs on thyroid and lipid profile of rats.

$\mathrm{T}_{3}$ is a more active form of thyroid hormone than $\mathrm{T}_{4}$, and both are synthesized in the thyroid follicles in low and high amount respectively. $\mathrm{T}_{4}$ is synthesized by monoiodination of $\mathrm{T}_{3}$ in liver. Serum TSH level is inversely correlated with serum $\mathrm{T}_{3}$ and $\mathrm{T}_{4}$ level (Tabassum et al. 2013). It has been reported in hypothyroidism significant decrease in serum $T_{3}$ and $T_{4}$ level occurs with increase in TSH level (Garber et al. 2012). Sublethal exposure of silver oxide nanoparticles lack capping agent of bioactive substances from medicinal plants or fungi, disrupt signalling of thyroid hormone during metamorphosis of Xenopus laevis (Daudin 1802) (Carew et al. 2015) but no recent work has been reported on impact of SNPs loaded with G. applanatum extract on thyroid profile of rats. Biochemicals of medicinal plants and mushrooms origin such as flavonoids, coumarins, alkaloids, minerals, essential oilcomponents, terpinene, other antioxidant compounds etc. and they directly influence the pituitary-thyroid axis and elevate or decrease the TSH level and directly or indirectly elevate or decrease the serum thyroid hormone level (Aleebrahim-Dehkordy et al.2018). In the present study, $400 \mathrm{mg} \mathrm{kg}^{-1}$ dose of SNPs significantly $(\mathrm{p}<0.05)$ increased $\mathrm{T}_{3}$ and $\mathrm{T}_{4}$ concentration and decreased TSH concentration compare to control and low dose treatment groups (Table 4). Thus, the present study can be correlated with the previous studies done as regards the hyper thyroid effect of natural plant and mushroom extract and can also be said that, SNPs loaded with $G$. applanatum extract act on pituitary-thyroid axis and increased the synthesis of $\mathrm{T} 3$ and $\mathrm{T} 4$.

Many studies have been done to understand the relation between thyroid function and chronic heart diseases (CHD) based on lipid profile and reported there is a significant positive correlation between TSH and lipid profile of CHD patients (Despre et al.2008). It has been studied and reported that, thyroid function modulates lipoprotein metabolism and also associated with some cardiovascular disease (CVD) risk factors which influence overall CDV risk (Rizos et al.2011). Significant increase in serum TSH level is directly associated with the increase in TC, LDL cholesterol and triglycerides (TGs) with decrease in serum HDL cholesterol levels (Rizos et al.2011). It has been reported that TC and LDL cholesterol levels elevate due to decreased activity of LDLreceptors in hypothyroidism (Teixeira et al.2008). $\mathrm{T}_{3}$ regulates the production of very low density lipoprotein (VLDL) and triglycerides (TG) by protecting oxidation of LDL and by regulation of gene expression LDL receptor's (Faure et al.2004). Increased levels of LDL, VLDL cholesterol and TG are the causative factors of chronic heart diseases and they enhance risks of atherosclerosis (Prenner et al.2014). It has also been reported that HDL cholesterol is capable of picking up LDL and VLDL cholesterol from blood, remove them from atheroma within arteries and transport them back to the liver for its excretion or reutilization (Despre et al.2008). Higher HDL cholesterol level has fewer risk of cardiovascular problems and are associated with better cardiovascular health, but there is no significant effect in cardiovascular system due to a further increase in HDL level after gaining its optimum level (Sirtori, 2006). Previously it was reported a, significant 
decrease in serum LDL cholesterol, TC level and an increase in HDL cholesterol of rats when treated with a mixture of gold and silver nanoparticles at $50 \mathrm{mg} \mathrm{kg}^{-1}$ body weight dose (Sulaiman et al.2015) Similar study has been done and reported similar significant hypocholesteromeric effect of silver nanoparticles on rat model (AlDujaili \& Al-Dujaili, 2016). Dandapat et al. (2014) also reported that, SNPs mediated by Aegle marmelos (L.) Corrêa leaf extract significantly decreases LDL and VLDL cholesterol level in rats when compare to normal and extract treated rat groups. In the present study $400 \mathrm{mg} \mathrm{kg-}$ 1 dose of SNPs loaded with $G$. applanatum extract significantly decreased total cholesterol, LDL cholesterol and triglyceride with significant increase in HDL cholesterol level (Table-5) compared to control and other treatment groups of rats. Thus, in the present study, significant increase in $\mathrm{T}_{3}, \mathrm{~T}_{4}$, and decrease in $\mathrm{TSH}$, influence the synthesis of HDL cholesterol with decrease in total cholesterol, LDL cholesterol and triglyceride and can be correlated with the previous finding based on hyper thyroid and hypolipidimic activity of mushroom extracts, to understand the relation of thyroid profile and lipid profile in hypothyroidism.

\section{Conclusion}

The SNPs loaded with G. applanatum extract had no acute toxicity. The finding is important, since, anything which is being used as medicine or probable medicine should definitely not show acute toxicity in studied models. The synthesized silver nanoparticles mediated by $G$. applanatum extract showed significant increase in $T_{3}, T_{4}$ level and decrease in TSH level. The nanoparticles also showed the hypocholesteremic activity. Thus, hyperthyroid and hypocholesteremic activities of nanopatricles provides new hope for application of SNPs in disorders associated with hypothyroidism and hypercholesterilimia

\section{Acknowledgments}

The authors would like to thank the Department of Zoology, Ranchi University, Ranchi, India for providing the working facilities. Authors would also like to thanks Department of Botany, Gauhati University, Assam, India for their help during the collection of mushroom.

\section{References}

Abbey BW, Nwachoko N \& Ikiroma GN. 2017. Nutritional value of cucumber cultivated in three selected states of Nigeria. Biochemistry Analytical Biochemistry 6(3): 1-3. https://doi.org/10.4172/2161-1009.10003 $\underline{28}$

Al-Dujaili ANG \& Al-Dujaili HHS. 2016. Assessment of osteocalcin level in association with type 2 diabetic patients. Research Journal of Pharmaceutical, Biological and Chemical Science 7(6): 1106-1114.

Aleebrahim-Dehkordy E, Ansaripour S, Kopaei MR \& Saberianpour S. 2018. Effects of substances on plants' active compounds on changes in the hormone levels of the pituitary-thyroid axis in hyperthyroidism and hypothyroidism. Pharmacognosy Review 12(23): 1-6. https://doi.org/10.4103/ phrev.phrev $48 \quad 17$

Almeida TCA, Larentis AL \& Ferraz HC. 2015. Evaluation of the stability of concentrated emulsions for lemon beverages using sequential experimental designs. Plos One 10(3): e0118690 [8]. https://doi.org/10.1371/journal.pone.0118690

Arya V, Thakur N \& Kashyap CP. 2012. Preliminary phytochemical analysis of the extracts of Psidium leaves. Journal of Pharmacognosy \& Phytochemistry 1(1): 1-6.

Bhattacharjee S. 2016. DLS and zeta potential - What they are and what they are not? Journal of Controlled Release 235: 337-351. https://doi.org/ 10.1016/j.jconrel.2016.06.017.

Bini M, Tondo C, Capsoni D, Mozzati MC, Albini B \& Galinetto P. 2018. Super paramagnetic $\mathrm{ZnFe}_{2} \mathrm{O}_{4}$ nanoparticles: The effect of $\mathrm{Ca}$ and $\mathrm{Gd}$ doping. Material Chemistry and Physics 204: 72-82. https://doi.org/10.1016/j.matchemphys.2017.10.033

Brady JB, Newton RM \& Boardman SJ. 1995. New uses for powder X-Ray diffraction experiments in the undergraduate curriculum. Journal of Geological Education. 43(5): 466-470.

Carew AC, Hoque ME, Metcalfe CD, Peyrot C, Wilkinson KJ \& Helbing CC. 2015. Chronic sublethal exposure to silver nanoparticles disrupts thyroid hormone signaling during Xenopus laevis metamorphosis. Aqua Toxicology. 159: 99-108. https://doi.org/10.1016/j.aquatox.2014.12.005

Dandapat S, Kumar M, Ranjan R \& Sinha MP. 2018. Pleurotus tuber- regium (Rumph. ex Fr.) Singer a potent source of antioxidant. Balneo Research Journal 9(3): 228-231. https://doi.org/10.12680/ balneo.2018.186

Dandapat S, Kumar M, Ranjan R \& Sinha MP. 2019. Toxicity of silver nanoparticles loaded with Pleurotus tuber-regium extract on rat. Biotechnologia Acta 12(3): 24-40. https://doi.org/10.15407/biotech12.03. $\underline{024}$

Dandapat S, Kumar M, Sinha MP. 2014. Effects of Aegle marmelos(L.) leaf extract and green nanoparticles on lipid profile. The Ecoscan. 5(Spl.1): 157-167.

Dandapat S, Sinha MP. 2015.Antioxidant and antiinflammatory activity of Pleurotus tuber-regium (Rumph. Ex.Fr.) Singer. Advances in Biological 
Research 9(3): 140-145.

Demers LM \& Spencer C. 2006. The thyroid pathophysiology and thyroid function testing. In: Tietz text book of clinical chemistry and molecular diagnostics (Burtis CA, Ashwood ER, Bruns DE, eds) New Delhi: Elsevier.

Despre JP, Cartier A, Cote M \& Arsenault BJ. 2008. The concept of cardiometabolic risk: Bridging the fields of diabetology and cardiology. Annals of Medicine 40(7): 514-523. https://doi.org/10.1080/0785389080 $\underline{2004959}$

Englebienne P, Hoonacker AV \& Verhas M. 2012. Surface plasmon resonance: principles, methods and applications in biomedical sciences. Journal of Spectroscopy 17(2-3): 255-273. https://doi.org/10. 1155/2003/372913

Faure P, Oziol L, Artur Y \& Chomard P. 2004. Thyroid hormone (T3) and its acetic derivative (TA3) protect low-density lipoproteins from oxidation by different mechanisms. Biochimie 86(6): 411-418. https:// doi.org/10.1016/j.biochi.2004.04.009

Firdhouse MJ, Lalitha P \& Sripathi SK. 2012. Novel synthesis of silver nanoparticles using leaf ethanol extract of Pisonia grandis (R. Br). Der Pharma Chemica 4(6): 2320-2326.

Garba SH, Sambo N \& Bala U. 2009. The effect of the aqueous extract of Kohautia grandiflora on paracetamol-induced liver damage in albino rats. Nigerian Journal of Physiological Scisciences 24(1): 17-23. https://doi.org/10.4314/njps.v24i1.463 $\underline{76}$

Garber JR, Cobin RH, Gharib H, Hennessey JV, Klein I, Mechanick JI, . . . Woeber KA. 2012. Clinical practice guidelines for hypothyroidism in adults: cosponsored by the american association of clinical endocrinologists and the american thyroid association. Thyroid. 22(12): 1200-1235. https:// doi.org/10.4158/EP12280.GL

Gujral SS. 2015. UV-Visible spectral analysis of boric acid in different solvent:a case study. International Journal of Pharmaceutical Sciences and Research 6(2): 830-834. http://dx.doi.org/10.13040/IJPSR.09 75-8232.6(2).830-34

Gurunathan S, Han JW, Park J-H, Kim JH. 2014. A green chemistry approach for synthesizing biocompatible gold nanoparticles. Nanoscale Research Letter 9: 248 [11]. https://doi.org/10.1186/ 1556-276X-9-248

Hirotus C, Tufik S \& Andersen ML. 2015. Interactions between sleep, stress, and metabolism: From physiological to pathological conditions. Sleep Science 8(3): 143-152. https://doi.org/10.1016/j. slsci.2015.09.002

Husen A \& Siddiqi KS. 2014. Phytosynthesis of nanoparticles: concept, controversy and application. Nanoscale Research Letter 9: 229 [24]. https://doi. org/10.1186/1556-276X-9-229

IMUSG (Instruction Manual User System Guide). IRPrestige-21 (P/N 206-72010) Shimadzu Fourier Transform Infrared Spectrophotometer 2002. Shimazu Corporation, Analytical \& measuring instrument division, Koyoto, Japan: IMUSG, 2002; available at from: http://www.nanocenter.umd.edu/ equipment/nanoopticslab/manuals/optics-03/private/l RPrestige21\%20Users\%20System\%20Guide.pdf

Jeong YT, Yang BK, Jeong SC \& Kim SM,Song $\mathrm{CH}$. 2008. Ganoderma applanatum: a promising mushroom for antitumor and immunomodulating activity. Phytotherapy Research 22(5): 614-619. https://doi.org/10.1002/ptr.2294

Kumar M \& Sinha MP. 2017. Green nanotechnology: synthesis of silver nanoparticles using aqueous leaf extract of Swertiachirayita. Notulae Scientia Biologicae 9(3): 443-448. https://doi.org/10.15835/ nsb9310107

Kumar TVC, Prasad TNVKV, Adilaxmamma K, Alpharaj M, Muralidhar Y \& Prasad PE. 2014. Novel synthesis of nanosilver particles using plant active principle aloin and evaluation of their cytotoxic effect against Staphylococcus aureus. Asian Pacific Journal of Tropical Disease 4(Supp. 1): S92-S96. https://doi.org/10.1016/S2222-1808(14)60421-7

Kumar VSS \& Rao KV. 2013. X-ray peak broadening analysis and optical studies of $\mathrm{ZnO}$ nanoparticles derived by surfactant assisted combustion synthesis. Journal of Nano- and Electronic Physics 5(2): 20-26.

Menaga D, Mahalingam PU, Rajakumar S \& Ayyasamy PM. 2012. Evaluation of phytochemical characteristics and antimicrobial activity of Pleurotus florida mushroom. Asian Journal of Pharmaceutical \& Clinical Research. 5(4): 102-106.

Mohanta YK, Nayak D, Biswas K, Singdevsachan SK, Allah EFA, . . . Mohanta TK. 2018. Silver nanoparticles synthesized using wild mushroom show potential antimicrobial activities against food borne pathogens. Molecules 23: 655 [18]. https://doi.org/10.3390/molecules23030655

Nanocomposix. 2015. Nanocomposix's guide to dynamic light scattering measurement and analysis: Guidelines for dynamic light scattering measurement and analysis 2015. Nanocomposix; Available from: https://cdn.shopify.com/s/files/1/0257/8237/files/nan oComposix_Guidelines_for_DLS_Measurements_an d_Analysis.pdf

Niemela $T$ \& Miettinen O. 2008. The identity of Ganoderma applanatum (Basidiomycota). Taxon 57(3): 963-966. https://doi.org/10.1002/tax.573024

Nikam AP, Ratnaparkhiand MP \& Chaudhari SP. 2014. Nanoparticles - an overview. International Journal of Research and Development in Pharmacy \& Life Sciences 3(5): 1121-1127.

Ogbonnia SO, Mbaka GO, Anyika EN, Osegbo OM \& Igbokwe NH. 2010. Evaluation of acute toxicity in mice and subchronic toxicity of hydroethanolic extract of Chromolaena odorata (L.) king and robinson (fam. Asteraceae) in rats. Agriculture \& Biology Journal of North America 1 (5): 859-865. https://doi.org/10.5251/abjna.2010.1.5.859.865

Oghenesuvwe EE, Nwoke EE \& Lotanna AD. 2014. Guidelines on dosage calculation and stock solution preparation in experimental animals' studies. Journal of Natural Sciences Research 4(18): 100-106.

Phenrat T, Kim HJ, Fagerlund F, Illangasekare T, Tilton RD \& Lowry GV. 2009. Particle size distribution, 
concentration, and magnetic attraction affect transport of polymer-modified $\mathrm{Fe} 0$ nanoparticles in sand columns. Environmental Science \& Technology 43(13): 5079-5085. https://doi.org/10.1021/es9001 $71 \mathrm{v}$

Prabu HJ, Johnson I. 2015. Plant-mediated biosynthesis and characterization of silver nanoparticles by leaf extracts of Tragiain volucrata, Cymbopogon citronella, Solanum verbascifolium and Tylophora ovate. Karbala Intrnational Journal of Modern Science 1(4): 237-246. https://doi.org/10.1016/ j.kijoms.2015.12.003

Prenner SB, Mulvey CK, Ferguson JF, Rickels MR, Bhatt $A B$ \& Reilly MP. 2014. Very low density lipoprotein cholesterol associates with coronary artery calcification in type-2 diabetes beyond circulating levels of triglycerides. Atherosclerosis 236(2): 244-250. https://doi.org/10.1016/j.atheros clerosis.2014.07.008

Rifa N \& Warnick GR. 2006. Lipids, lipoproteins, apolipoproteins and other cardiovascular risk factors. In: Tietz text book of clinical chemistry and molecular diagnostics (Burtis CA, Ashwood ER, Bruns DE, editors). New Delhi: Elsevier.

Rizos CV, Elisaf MS \& Liberopoulos EN. 2011. Effects of thyroid dysfunction on lipid profile. The Open Cardiovascular Medicine Journal 5: 76-84. https:// doi.org/10.2174/1874192401105010076

Salata OV. 2004. Applications of nanoparticles in biology and medicine. Journal of Nanobiotechnology 2(3): 1-6. https://doi.org/10.1186/1477-3155-2-3

Saleem U, Ahmad B, Ahmad M, Erum A, Hussain K \& Bukhari NI. 2016. Is folklore use of euphorbia helioscopia devoid of toxic effects? Drug \& Chemical Toxicology. 39(2): 233-237. https://doi.org/10.3109/ 01480545.2015.1092040

Saleem U, Amin S, Ahmad B, Azeem H, Anwar F \& Mary S. 2017. Acute oral toxicity evaluation of aqueous ethanolic extract of Saccharum munja Roxb. roots in albino mice as per OECD 425 TG. Toxicol Reports 4: 580-585. https://doi.org/10.1016/j.toxrep.2017. 10.005

Shah M, Fawcett D, Sharma S, Tripathy SK \& Poinern GEJ. 2015. Green synthesis of metallic nanoparticles via biological entities. Materials 8(11): 7278-7308. https://doi.org/10.3390/ma8115377

Singh R, Singh AP, Dhingra GS \& Shri R. 2014. Taxonomy, physicochemical evaluation and chemical investigation of Ganoderma applanatum and G. browni. International Journal of Advanced Research 2(5): 702-711.

Sirtori CR. 2006. HDL and the progression of atherosclerosis: new insights. European Heart Journal Supplement. 8(Supp. F1): 4-9. https:// doi.org/10.1093/eurheartj/sul034
Sowmya C, Lavakumar V, Venkateshan V, Ravichandiran V \& Saigopal DVR. 2018. Exploration of Phyllanthus acidus mediated silver nanoparticles and its activity against infectious bacterial pathogen. Chemistry Central Journal 12(42): 1-9. https:// doi.org/10.1186/s13065-018-0412-7

Subramanion LJ, Zakaria Z, Chen Y, Lau LY, Latha LY \& Sasidharan S. 2011. Acute oral toxicity of methanolic seed extract of cassia fistula in mice. Molecules 16(6): 5268-5282. https://doi.org/10.3390/molecu les16065268

Sujatha S, Tamilselvi S, Subha K \& Panneerselvam A. 2013. Pathogenicity of bacterial isolates to Catla catla. International Journal of Current Microbiology \& Applied Sciences 2(12): 575-584.

Sulaiman FA, Akanji MA, Oloyede HOB, Sulaiman AA, Olatunde A, . . Adeyemi OS. 2015. Oral exposure to silver/gold nanoparticles: Status of rat lipid profile, serum metabolites and tissue morphology. Journal of Medical Sciences 15: 71-79. https://doi.org/ 10.3923/jms.2015.71.79

Tabassum W, Kullu AR \& Sinha MP. 2013. Effects of leaf extracts of Moringa oleifera on regulation of hypothyroidism and lipid profile. The Bioscan 8(Sup.2): 665-669.

Teixeira PF, Reuters VS, Ferreira MM, Almeida CP, Reis FA, . . . Vaisman M. 2008. Lipid profile in different degrees of hypothyroidism and effects of levothyroxine replacement in mild thyroid failure. Translation Research 151: 224-231. https://doi.org/ 10.1016/j.trsl.2007.12.006

Udovcic M, Pena RH, Patham B, Tabatabai L \& Kansara A. 2017. Hypothyroidism and the heart. Methodist De Bakey Cardiovascular Journal 13(2): 55-59. https://doi.org/10.14797/mdcj-13-2-55

Unnikrishnan AG \& Menon UV. 2011. Thyroid disorders in India: An epidemiological perspective. Indian Journal Endocrinology \& Metabolism 15(S2): 78-81. https://doi.org/10.4103/2230-8210.83329

Wang Y, Ding L, Yao C, Li C, Xing X, . . Wu M. 2017. Toxic effects of metal oxide nanoparticles and their underlying mechanisms. Science China Materials. 60(2): 93-108. https://doi.org/10.1007/s40843-0165157-0

Zhu Y \& Tan ATL. 2015. Discrimination of wild-grown and cultivated Ganodermalucidum by Fourier transform infrared spectroscopy and chemometric methods. American Journal of Analytical Chemistry. 6: 830-840. http://dx.doi.org/10.4236/ajac.2015. $\underline{65047}$

ZNUM (Zetasizer Nano User Manual). Zetasizernano series user manual 2013 [internet] Malvern Instruments Ltd., Malvern, United Kingdom: ZNUM; 2013. Available from: https://www.malvernpana lytical.com/en/learn/knowledge-center/user manuals/ MAN0485EN.html 